\title{
Rural Poverty and Land Degradation: A Review of the Current State of Knowledge
}

\author{
SOHAIL JEHANGIR MALIK and HINA NAZLI
}

\section{BACKGROUND}

By highlighting the lack of rigorous evidence and calling for a greater understanding of the interaction of the two processes, a recent study [Nelson et al. (1997)] has called into question the strong perception that poverty is both a consequence as well as a cause of resource degradation. ${ }^{1}$ This perception which is widely held is strongly evident in the writings of the multilateral development agencies such as the World Bank (1990) and IFAD (1992) and exists despite extensive reviews which indicate that the short- and long-term implications of land degradation are not very clear [see Scherr and Yadav (1995)]. Similarly, while knowledge about poverty is expanding rapidly, thanks in large parts to the massive international focus and resources brought to bear on its understanding in the past ten

Sohail Jehangir Malik is Chief Executive Officer at the Innovative Environmental Technologies, Inc., USA, and Hina Nazli is Research Economist at the Pakistan Institute of Development Economics, Islamabad, respectively.

Authors' Note: The paper is based on an earlier report Malik (1999) completed for the Technical Advisory Committee (TAC) of the Consultative Group for International Agricultural Research (CGIAR) funded by the Food and Agriculture Organisation (FAO), Rome. The paper should not be taken, in any way, to represent the official position of these organisations.

${ }^{1}$ This perception aggregates over many diverse situations that adds to the confusion. Generally societies are composed of poor as well as non-poor individuals and poverty is characterised by differential access to resources especially land. Stating that the poor in a particular region behave differently from the non-poor in terms of their relationship to land and are impacted differentially by it is not the same as saying that generally low levels of development in a region are both a cause as well as a consequence of resource degradation. While areas with low levels of development may have a larger proportion of the poor, regions with relatively better levels of development can also contain significant proportions of poor people. In order to evaluate conclusively if the poor behave differently from the non-poor, it is crucial to be able to maintain conceptual and analytical rigor. For this it is important to control for general levels of development, institutions, markets, infrastructure, resource quality and quantity and relationships that govern the use of resources. 
years or so; the existing state of knowledge is still far from providing a comprehensive understanding of all the complex dimensions of its processes. ${ }^{2}$ The understanding of the interactions of poverty and land degradation is even less clear and limited. ${ }^{3}$

This paper reviews the existing knowledge about the relationship between poverty and land degradation and draws implications for research.

\section{DEFINING LAND DEGRADATION AND SUSTAINABILITY}

There are several definitions of land degradation. Land ${ }^{4}$ degradation is generally defined as the reduction in the soil's ability to contribute to crop production [Blaikie and Brookfield (1987)] and as a change to land that makes it less useful for human beings [Wasson (1987)]. Land degradation can take many forms. ${ }^{5}$ Land degradation ${ }^{6}$ effects are often cumulative. The off-site effects (sedimentation of reservoirs and deposition of silt on downstream fields), both positive and negative, can also be considerable. A formidable problem exists because there is no simple relationship between the physical phenomena and the perceptions of land by human beings. What is observed in the present is the result of the interaction of several complex processes over long periods of time. For complete detection and measurement of land degradation, a system is needed for monitoring change in physical, biological and social phenomena. ${ }^{7}$

${ }^{2}$ Conclusion of the World Bank's workshop on the "Future of Poverty Analysis in the Bank", March 16, 1997 reported in Malik (1997).

${ }^{3}$ Studies on the direct empirical verification of the relationship between poverty and land degradation are extremely scarce. Scherr and Yadav (1995) after their comprehensive survey of available literature conclude that no consistent relationship between poverty and land degradation can be established.

${ }^{4}$ The concept of land used in such studies is broad. It is the extensive system of physical and biological materials and processes associated with the interface of the solid earth, terrestrial water bodies and the air, and the works of human beings [Chisholm and Dumsday (1987)].

${ }^{5}$ Scherr (1998) classifies these to include: crusting, compaction, sealing, wind erosion, water erosion, devegetation, over-tillage, impeded drainage, waterlogging, reduced waterholding capacity, reduced infiltration, salinisation, alkalinisation, acidification, nutrient leaching, removal of organic matter, burning of vegetative residues, nutrient depletion, over-application of agrochemicals, industrial contamination, decline in vegetative cover, decline in biodiversity, decline in species composition, decline in availability of valued species. Land degradation involves aspects of physical soil management soil Water management, soil nutrient and organic matter management, soil biology management, vegetation management.

${ }^{6}$ Degradation and erosion are not the same although the terms are often used interchangeably. Erosion is only one (though probably the most well known and significant) possible form of degradation [Pagiola (1994)].

${ }^{7}$ For an excellent discussion of detection and measurement issues of land degradation processes see Wasson (1987). 
The heterogeneity of the situations and the complex and changing (over time) interaction of the several processes involved have negative implications for precise measurement. $^{8}$

Concern with land degradation has heightened due to the increasing focus in policy circles on sustainability. However, sustainability is often confused to imply zero depletion of the natural resource base or zero environmental costs. However, "agricultural production that imposes some resource depletion and environmental costs can be sustainable as long as the costs of depletion and environmental damage are consistent with rising per capita welfare" [Crosson and Anderson (1993)]. From an economic perspective, degradation only occurs beyond the socially defined optimal use level. Such degradation occurs where individuals cannot or do not optimise returns to their resources (e.g., due to inadequate information) and/or because there is a divergence between private and social interests (e.g., externalities or inappropriate public policies) [see, for example Scherr and Yadav (1995) and Binswanger (1989)].

There is general recognition that data on the physical processes of land degradation as well as on its economic and social consequences are sparse [Scherr and Yadav (1995)]. Earlier reviews of the evidence on land degradation around the world have also found this evidence to be "extraordinarily skimpy". "No country has comprehensive estimates of the productivity consequences of land degradation or the rates of degradation from current practices" [Crosson and Anderson (1992)]. Several other authors, including Biot et al. (1995), recognising this inadequacy, have called for a thorough review of experimental and field data and a sharper focus, particularly, on robust and cheap methods of measurement in order to improve the understanding of the physical processes involved.

The problems associated with drawing representative samples for plot-level measurement have meant that most aggregate estimates are based on non-scientific methods of "raising" the information. Most estimates of the impact of land degradation are based on "objective assessments" by experts. Available aggregate estimates of the cost of degradation have to be taken with even greater caution since

${ }^{8}$ Much of what we know about the extent and nature of land degradation is based on (1) anecdotal evidence (2) suspended sediment measurements and (3) plot-level soil loss measurements. The anecdotal evidence, though generally visually spectacular, is often non-representative and does not control for the effects of other factors. The suspended sediment measurements are difficult to undertake and do not provide information on the effects on yields. The plot-level soil-loss measurements come from test plots. There are also serious issues of the representativeness of field conditions and practices associated with these. Measurements are generally carried out in short periods-whereas actual soil loss varies substantially because of changes in other conditions. What are needed ideally are estimates of long-term average loss. Moreover, these measurements are generally limited to soil loss and not productivity loss. These measurements generally assume that soil moved from one field is soil lost, whereas it might have moved from one field to another. Because of these data problems often it is very difficult to decide on the existence or severity of land degradation [Pagiola (1994)]. 
they are based on standard formulas relating certain levels of degradation to estimates of yield losses. Attempts to go from the estimates of the effect of yield losses at the plot level to aggregate estimates of the socioeconomic impact at the national or regional level have often been dubbed as "giant leaps of faith". Even at the plot level the problems associated with measuring the physical and social value consequences of alternative natural resource management practices and technologies are "big and complex" and not amenable to perfect solutions [Crosson and Anderson (1993)].

In most countries the data used for such estimates generally comes from a few studies that were not originally designed to generate estimates for the whole country. ${ }^{9}$ Moreover, the capacity to monitor changes over time is limited by the weak statistical foundations and the lack of comparability in the available data.

The Global Land Assessment of Degradation (GLASOD) ${ }^{10}$ is the first major exercise that has sought to maintain some consistency in definitions in its endeavour to obtain aggregate estimates of land degradation [Oldeman, Hakkeling and Sombroek (1990)]. The comparative study of dry lands by Dregne and Chou (1992) represents another important effort. ${ }^{11}$ While the GLASOD exercise was designed to study the problem at the continental scale, the latter study was designed for analysis at the national level but was limited by the availability of national studies. The study [ASSOD] by van Lynden and Oldeman (1997) represents a recent attempt at estimating land degradation. While the methodology is basically the same as that for the GLASOD study, it permits analysis at the national level while the GLASOD was focused on a larger regional level.

The GLASOD study estimated that nearly 2 billion hectares (i.e. 22.5 percent) of the 8.7 billion hectares of vegetated area (agricultural land, pasture, forest and woodland) have been degraded since the mid century. This study estimated that some 3.5 percent of the total have been degraded so severely as to be reversible only through costly engineering measures if at all. Just over 10 percent has been moderately degraded and is reversible only through significant on-farm investments. Another nearly 9 percent is lightly degraded and easily reversible through good land

\footnotetext{
${ }^{9}$ For example U.S estimates of the magnitude of soil erosion and the effects of soil erosion on land productivity come from only two sample surveys [Crosson (1986)].

${ }^{10}$ The GLASOD estimates are also subjective because these are based on experts' estimation of land degradation since the Second World War.

${ }^{11}$ Studies listed in Scherr (1998) by methods used for assessment of soil degradation impacts include: Qualitative assessments: Pagiola and Dixon (1997); Oldeman et al. (1991); van Lynden and Oldeman (1997); Seghal and Abrol (1994) and Dregne (1990, 1992). Biophysical models of degradationyield relationships: Aune et al. (1997); Kilasara et al. (1995); Stocking and Benites (1996) and Cassman et al. (1995) with secondary price data to obtain estimates of value: Aune (1995); Pagiola (1997); Littleboy et al. (1996). Aggregate, gross valuation of economic losses due to degradation and cost benefit analysis: Pimentel (1995); Young (1993); Lutz et al. (1994); McIntire (1994); White and Jickling (1994). Econometric models: Byringiro and Reardon (1996); Rozelle et al. (1997); Lindert (1996); Bojo (1991); Rozelle et al. (1997); Byringiro and Reardon (1997); Alfsen et al. (1997); Agcaoli et al. (1995); Higgins et al. (1983). Comprehensive Assessments based on disaggregated data (by soil type, farming system, crop): Stoorvogel et al. (1993); Smaling and Stoorvogel (1993); Repetto et al. (1989) and Lal (1995).
} 
management. The GLASOD estimates indicate that nearly one-half of this vegetated area is under forest, of which about 18 percent is degraded; 3.2 billion hectares is under pasture, of which 21 percent is degraded and nearly 1.5 billion hectares is in cropland, of which 38 percent is degraded. Water erosion is the principal cause of degradation. Wind erosion is another important cause, particularly in dry lands and areas where land forms are conducive to high winds. Chemical degradation, such as salinisation and nutrient loss, is often the result of cropping practices. It accounts for a smaller overall proportion of degraded lands but more than 40 percent of cropland degradation. Physical degradation such as compaction accounts for a smaller proportion of degraded area. According to the GLASOD estimates degradation of cropland appears to be most extensive in Africa, affecting 65 percent of cropland area compared with 51 percent in Latin America and 38 percent in Asia. Degradation of pasture is also most extensive in Africa, affecting 31 percent, compared with 20 percent in Asia and 14 percent in Latin America. Forest land degradation is most extensive in Asia, affecting 27 percent of forest land compared with 19 percent in Africa and 14 percent in Latin America.

Land degradation can lead to declining potential yields on the farm. But, fertiliser use or changing the land use can hide the effects of this degradation for long periods. As such it is almost impossible to establish a one-to-one relationship between the amount of degradation and the effect on yields. Moreover, the level at which yields are affected by changes in land quality can differ by the type and variety of crop grown and by type of soil and its depth etc. While measurements of land degradation generally cover only a short period of time, any measurable effect on crop yields could however, take long periods to appear because of the cumulative nature of land degradation.

For developing countries the literature on land degradation is even more qualitative and less rigorous than that available for developed countries. The difficulty of modelling complex farming systems and the lack of necessary data both contribute to this paucity. ${ }^{12}$ Most glaring is the lack of knowledge of the effects of degradation on social welfare. "Most of the technical literature on the socioeconomic aspects of land degradation can be classified into three broad categories: soil conservation as an input in agricultural production; top soil as a natural resource, somewhere between nonrenewable and renewable; and the effects of land degradation on common property resources and externalities" [Anderson and Thampapillai (1990)]. Studies at the household level that attempt to rigorously verify differences in behaviour between the poor and the non-poor with respect to land are generally difficult to find.

\footnotetext{
${ }^{12}$ The lack of technical information such as rates of soil loss and physical parameters such as those required for the definition of the universal soil loss equation (USLE) leads some studies to use site parameters from specific developed country locations [see, for example Veloz et al. (1985)].
} 
Scherr (1998), based on her detailed review of this literature, ${ }^{13}$ concludes that "many studies examine the gross impact of degradation on crop production ${ }^{14}$ [but] very few examine the net effect, taking into account price effect, substitution of supply by other producing areas, or other secondary impacts. [And moreover] very few studies incorporate into their analysis any active farmer response to degradation" [Scherr (1998)]. Scherr could find only three studies that provided data relevant to the assessment of human welfare impacts. These welfare assessments use different indicators to assess the impact at national or international levels. ${ }^{15}$

\section{POVERTY AND LAND DEGRADATION}

Lipton (1997) states forcefully that it is irrational to expect people to knowingly behave in ways that destroy resources necessary for their survival or that of their future generations ${ }^{16}$ unless very strong pressures to do so are present. ${ }^{17} \mathrm{He}$ lists four such pressures generally discussed in the literature. ${ }^{18}$ These include (1) increases in population as mortality falls but fertility declines lag and (2) declines in common property resources (CPRs) [see Jodha $(1985,1986,1991)]$. In addition there are international pressures; including (3) interest rate changes and (4) technology transfers [Lipton (1997)].

\footnotetext{
${ }^{13}$ Scherr (1998) contains the most comprehensive review of studies showing the impact of land degradation. At the global level she reviews UNCOD (1977); UNEP (1980); Higgins et al. (1983); Harrison (1984); Mabbutt (1987); Buringh and Dudal (1987); Dregne and Chou (1992); Oldeman et al. (1992); Pimentel et al. (1993); Steiner and Herdt (1993); Crosson (1994); Agcaoli et al. (1995); Dyson (1996); Stocking and Benites (1996); Crosson (1997) and Scherr and Yadav (1995).

${ }^{14}$ Oodit and Somonis (1992) estimated that salinity has reduced the yield of major crops by 30 percent in the fifteen million hectares of irrigated lands in Pakistan. The study by Crosson (1995) indicates that the average productivity losses in the dry lands between 1945 and 1990 were in the range of 11.9 to 13.4 percent. Globally he calculates that if all strongly and extremely degraded lands were restored there would be a 15 percent yield increase. Given the spectacular growth in global food production and the secular declines in grain prices over this period it is obvious that other factors must have compensated for the effects of degradation on aggregate performance.

${ }^{15}$ The CGE model for Nicaragua, one of these three studies, finds a counter-intuitive positive effect of degradation on peasant consumption [Alfsen et al. (1996) reported in Scherr (1998)].

${ }^{16}$ Often the problems of poverty, population and the environment are intertwined: earlier patterns of development and the pressure of rapidly expanding population mean that many of the poor live in areas of acute environmental degradation [World Bank (1990)].

${ }^{17}$ The World Bank maintains a similar position. "The poor do not wilfully degrade the environment but poor families often lack the resources to avoid degrading their environment. The very poor, struggling at the edge of subsistence, are preoccupied with day to day survival. It is not that the poor have inherently short horizons; poor communities often have a strong ethic of stewardship in managing their traditional lands. But their fragile and limited resources, their often poorly defined property rights, and their limited access to credit and insurance markets prevent them from investing as much as they should in environmental protection. When they do make investments they need quick results [World Bank (1992), p. 30].

${ }^{18}$ According to the World Bank the main source of pressures generating problems of degradation is thought to lie in rapid population growth. Other pressures come from the widespread use of natural resource intensive technologies; ineffective regulation of common property resources; land tenure systems that do not secure long terms rights to land use; and policies that distort the prices of non-renewable resources [World Bank (1991) a cited in Biot et al. (1995)].
} 
Poverty generates significant incentives to have large families. Traditionally the impact of population growth on natural resources was discussed in terms of "carrying capacity". ${ }^{19}$ Conceptually, if nothing else changes, then it is assumed that the increasing population will put demands on the resources that can no longer be met without damaging the ability of these resources to support human life. Social and economic factors such as trade, technology, consumption preferences and levels of inequality can alter the carrying capacity. Poor people will often use migration as a coping strategy. However, migration may not always benefit rural environments since the absolute numbers of rural people may continue to increase.

Lipton (1997a) notes that technology generation in agriculture remains exogenous to most of the developing countries and is not driven significantly by their resource saving or other requirements. This is the classic choice of techniques problem highlighted in the literature on industrial development during the 1970s that first made popular terms such as "technological determinism." This argument holds that the technically efficient techniques are generally developed in the capitalabundant labour-scarce developed countries and generally reflect the factor endowments of these countries.

\section{Impact of Degradation on the Poor ${ }^{20}$}

The poor generally have access only to areas that have higher risk for health and income generation. ${ }^{21}$ And they generally lack the resources to reduce the exposure to the risk or to invest in alleviating the causes of such risk. Environmental degradation therefore can affect the health and nutrition status of the poor and lower their productivity. This can happen both directly through, for example, lower yields per unit of labour or land because of reduced soil quality, and indirectly through the reduced physical capacity of labour to produce because of malnutrition and poor health. Even in cases where the poor are healthy labour productivity can be low due

\footnotetext{
${ }^{19}$ Attempts to compare current and projected populations to potential population supporting capacities (PSCs) at certain levels of technology have found that with low input technologies (typical of current production practices) population levels in 1975 had already exceeded carrying capacities in several West African countries. The study by Higgins, Kassam and Miken (1983) predicted that 7 of the 8 Sahelian countries will exceed population-supporting capacities by the year 2000. Regional imbalances and environmental damage were greatest in the Sahelo Sudanian zone despite low population densities.

${ }^{20}$ Much of the discussion in this and the following subsection draws heavily from Mink (1993).

${ }^{21}$ The most debilitating risk is that of drought in semi arid tropical areas. The combination of poverty and drought can have serious environmental consequences that threaten future agricultural productivity and the conservation of natural resources. Poor people are induced to scavenge more intensively during droughts, seeking out wood and other organic fuels, wild life and edible plants, both to eat and to sell. This scavenging aggravates deforestation and damage to watersheds and soil already under stress from the drought. The problem is aggravated in common property pastoral farming where farmers carrying extra cattle as insurance against drought may exploit and over burden the carrying capacity of the land increasing the likelihood of permanent damage. Small ruminants can be exceptionally damaging to resources. Poorer households are generally responsible for raising small ruminants, which are allowed to graze low quality resources especially on open access and common property land [IFAD (1992)].
} 
to increased time being allocated to less-productive activities such as fuel wood collection and away from agriculture and other income generating activities [Kumar and Hotchkiss (1988)]. In terms of the productivity of the resources that the poor manage, the decline is intricately related to the poverty-population-environment interaction [Mink (1993)]. Where the poor depend on biomass fuel and confront increasing fuel wood scarcity they often shift to using animal dung, fodder and crop residues for fuel. The quantities of these materials that are returned to the soil are thus reduced and its fertility declines. ${ }^{22}$ Non-replenishment of soil nutrients leads to soil exhaustion as fuel wood supplies diminish and animal manure is increasingly used as a fuel substitute. Poverty forces a trade-off between the immediate demands for fuel for cooking and heating and manure for the land. The time-preference argument suggests that the immediate and urgent needs be satisfied. Mortimore (1989) shows how soil exhaustion occurs when certain nutrients are taken from the soil but are not replenished naturally or artificially with fertilisers. A homogenous crop, usually a cash crop, grown repeatedly on the same piece of land can lead to soil exhaustion. ${ }^{23}$ Increasing population pressures on land can also lead to shortened fallow periods and this coupled with the farmer's inability to apply variable inputs more intensively because of poverty, can lead to decreased soil productivity. Productivity, especially, in open-access natural resources or of resources under deteriorating common property management may often decline due to over-use.

\section{Poverty Impact on Resource Management}

Poverty is generally assumed to impose short time horizons. ${ }^{24}$ Theoretically this results from the poor having high rates of pure time preference which lowers the ability to forego consumption today. This leads to using up savings previously set aside for later consumption and to borrowing if access to credit is available. The implications of a high subjective discount rate are rapid resource extraction to meet present income or consumption needs and low investment in natural resources to improve future returns. Overgrazing of pastures and shortening of fallow periods can result from the high subjective discount rates. Similarly, farmers are less likely to make natural resource investments where returns are expected after a number of years. These factors combine to lead to a wide divergence between private and social discount rates. ${ }^{25}$ The empirical evidence on whether the poor really do have high

\footnotetext{
${ }^{22}$ The loss in grain production as a result of diverting dung from fertiliser to fuel use in Africa, the near east and Asia has been estimated at up to 20 million tons per year [Redclift and David (1990)].

${ }^{23}$ Given the declining yields on the land and the inability to find the institutional support in terms of fertiliser and access to credit and technology, poor farmers are forced to sell their land and become land less peasants or to encroach on new forest lands [de Graaff (1993)].

${ }^{24}$ This is not to say that short time horizons are exclusive to the poor.

${ }^{25}$ Veloz et al. (1985) in their analysis of a soil conservation project in the Dominican Republic show that soil conservation is profitable on only 20 percent of the land area using private analysis. Alternatively social analysis based on discount rates that reflect the society's inter temporal preferences, indicate that soil conservation is viable in nearly 70 percent of the land area.
} 
rates of time preference is limited and sketchy. ${ }^{26}$

Risk aversion can lead to a short time horizon. To the extent that outcomes in the future become less certain than outcomes closer to the present, people will prefer to trade the more uncertain outcomes for the more certain ones. Risk aversion amongst farmer is widely documented [e.g., Binswanger (1980); Walker (1981); Grisley (1980) and Sillers (1980)]. The results of these studies generally indicate that attitudes of the poor to risk are not distinguished from those of the non-poor by innate or acquired characteristics but by the higher levels of risk faced by the poor and by the greater constraints to coping with these risks. Deteriorating land quality brings not only poorer yields but also greater yield fluctuations and hence higher risk. ${ }^{27}$ To the extent that access to common property resources serves as insurance for the poor in times of setbacks to the primary sources of income, the decrease in access can increase the risk. Migration can benefit the environment through mitigating risk. $^{28}$ Individual migration is increasingly seen as an outcome of family decisionmaking, particularly in response to uninsured risks [Stark (1991)].

The poor face greater constraints to managing their risks. Their assets and stored production are generally minimal. Their access to credit and insurance is generally limited and or non-existent. Rural credit and insurance markets in developing countries are notoriously fragmented. In most cases there is also a gender bias so that poor women have far less access to mechanisms for managing risk than their male counterparts. If risk is allowed for, the interest rate incentive to deplete is probably sharpened. "Higher interest rates reduce the present value burden of long term future risks relative to that of near term risks (and costs). The land use patterns are therefore shifted towards activities with long-term risks such as possible longterm resource degradation. There is thus a powerful resource depleting incentive created by rising interest rates. Costly credit undoubtedly shifts the composition — of inputs, outputs, techniques, investment, consumption and savings - sharply in a resource depleting direction” [Lipton (1997)].

\section{The Links between Poverty and Land Degradation- Mixed Empirical Evidence}

The study by Grepperud (1997) concludes that in the relationship between poverty, land degradation and climatic uncertainty it is unclear whether poverty in general induces farmers to manage their resources poorly in the long run. The study

\footnotetext{
${ }^{26}$ The ICRISAT study by Pender and Walker (1990) which estimated high rates of time preference through experimental games for a small sample of poor farmers in India is generally cited as an example.

${ }^{27}$ Reardon and Vosti (1997) note that generalised poverty erodes traditional community risk sharing or insurance institutions by over taxing them; forcing the poor to fend for themselves often turning to resource mining and commons dependent strategies.

${ }^{28}$ Remittances are an important coping strategy for rural poor [Alderman and Paxson (1992)].
} 
by Scherr, Jackson and Templeton (1995) also found no consistent relationship between population density or the frequency with which land is used for productive purposes and degradation of the land. Population growth and poverty, they noted, create both incentives and disincentives for land degradation. There is an extreme dearth of studies that seek to rigorously test these relationships. The lack of appropriate data underlies this paucity. To do this effectively information is required not only on the physical aspects of the land but also of poverty and a host of other factors that need to be controlled for. Such data are not available at the present time. Reliance therefore has to be placed on studies from which the relationships can be inferred.

Most of the available studies look at the problem in terms of the behaviour of small-scale farmers and land degradation [see, for example Southgate (1988); Pagiola (1995) and Mortimore (1989)] and the lack of secure land tenure as the primary reason for poor farmers cultivating their land excessively to exhaustion for the simple reason that they have no vested interest in conserving an asset that they do not own [see, for example, Southgate (1988); Mink (1993) and Repetto et al. (1989)]. However, much of the literature that assumes that poverty leads to degradation cannot explain instances of (materially) poor communities living sustainably with their environment for centuries.

\section{IMPLICATIONS FOR RESEARCH POLICY}

There is a serious need for strategies that integrate research on commodity improvement with the conservation and management of natural resources. This has long been recognised as one of the major organisational challenges facing the future of international agricultural research. ${ }^{29}$

Answers to several questions postulated in Scherr (1998) can help to clarify the process of priority setting in the area of research on poverty and land degradation. Specifically research needs to answer questions such as:

Who are the principal resource users? What are their actual (as opposed to theoretical) incentives for investment and dis-investment in important natural resources? What are the farmer's and the community's perceptions of resource degradation? What is their understanding of the ecological processes involved when production systems change or their strategies of adapting to degradation change? What is the empirical evidence of resource degradation at the farm, community and regional levels, and the realistic estimates of the costs and benefits of resource rehabilitation for the different actors?

${ }^{29}$ See the March 1993 CGIAR Report of the Centre Director's Working Group on Eco-regional Approach (Annex 1, p.3) 
can greatly facilitate effective policy making in this area. Additionally such research needs to differentiate between the behaviour of poor as opposed to the non poor in order to afford a fuller understanding of the interaction of these complex phenomena.

\section{REFERENCES}

Adams, R. (1995) Sources of Income Inequality and Poverty in Rural Pakistan. International Food Policy Research Institute, Washington D.C. (Research Report No. 102.)

Agcaoili, M., N. Perez, and M. Rosegrant (1995) Impact of Resource Degradation on Global Food Balances. Paper prepared for the workshop on Land Degradation in the Developing World: Implications for Food, Agriculture, and Environment to the Year 2020, April 4-6, Annapolis, Maryland. International Food Policy Research Institute. Washington, D. C.

Alderman, H., and C. Paxson (1992) Do the Poor Insure? A Synthesis of the Literature on Risk and Consumption in Developing Countries. The World Bank and Woodrow Wilson School Princeton University. (Mimeographed.)

Alfsen, K.M. et al. (1997) Soil Degradation and Economic Development in China. Environment and Development Economics 2: 119-143.

Alexandratos, N. (eds) (1995) World Agriculture: Towards 2010. New York: FAO and John Wiley \& Sons.

Anderson, J. R., and J. Thampapillai (1990) Soil Conservation in Developing Countries: Project and Policy Intervention. Policy Research and External Affairs. World Bank, Washington D.C. (Policy and Research Series No. 8.)

Aune, J. B. (1995) Predicting Soil degradation in Tanzania-A System Analysis Approach. Norwegian Journal Agricultural Sciences Supplement No. 21: 47-60.

Aune, J. B., I. K. Kullaya, M. Kilasara, F. S. B. Kaihura, B. R. Singh and R. Lal (1995) Consequences of Soil Erosion on Soil Productivity and Productivity Restoration by Soil Management in Tanzania. In R. Lal (ed) Soil Quality and Sustainable Agriculture. Ann Arbor: Ann Arbor Press.

Binswanger, H. (1980) Attitudes Toward Risk: Experimental Measurement in Rural India. American Journal of Agricultural Economics 62:3 395-407.

Binswanger, H. P. (1989) Brazilian Policies that Encourage Deforestation in the Amazon. Washington, D.C. (World Bank Environment Department Paper No. 16.)

Binswanger, H. P., and V. Ruttan (1978) Included Innovation: Technology Institutions and Development. Baltimore: The Johns Hopkins University Press.

Biot Y., P. M. Blaikie, C. Jackson, and R. Palmer-Jones (1995) Rethinking Research on Land Degradation in Developing Countries. World Bank, Washington, D.C. (World Bank Discussion Paper No. 289.)

Blaikie, P. (1985) The Political Economy of Soil Erosion in Developing Countries. 
Harlow: Longman.

Blaikie, Piers, and Harold Brookfield (1987) Land Degradation and Society. London: Methuen \& Co.

Bojo, Jan (1991) The Economics of Land Degradation: Theory and Applications to Lesotho. Stockholm: The Stockholm School of Economics, Sweden. 352p.

Boserup, E. (1965) The Condition of Agricultural Growth. London: Allen and Unwin.

Buringh, P., and R. Dudal 1987 Agricultural Land Use in Space and Time. In M.G. Wolman and F. G. A. Fournier (eds) Land Transformation in Agriculture. New York: John Wiley. 9-45.

Byringiro, F., and T. Reardon (1996) Farm Productivity in Rwanda: Effects of Farm Size, Erosion, and Soil Conservation Investments. Agricultural Economics 15: 127-136.

Cassman, K., R. Steiner, A. E. Johnson (1995) Long-term Experiments and Productivity Indexes to Evaluate the Sustainability of Cropping Systems. In V. Barnett, R. Payne and R. Steiner (eds) Agricultural Sustainability, Environment and Statistical Considerations. Chichester: John Wiley and Sons. 231-244.

Chisholm, A., and R. Dumsday (eds) (1987) Land Degradation: Problems and Policies. London: Cambridge University Press.

Crosson, P. (1986) Soil Erosion and Policy Issues. In T. Phipps, P. Crosson and K. Price (eds) Agriculture and the Environment. Washington, D.C.: Resources for the Future, 35-73.

Crosson, P. R. (1995) Soil Erosion and its On-Farm Productivity Consequences: What do We Know? Resources for the Future, Washington, D.C. (Resources for the Future Discussion Paper 95-29.)

Crosson, P. R. (1994) Degradation of Resources as a Threat to Sustainable Agriculture. Paper Prepared for the First World Congress of Professionals in Agronomy, Santiago, Chile. September 5-8.

Crosson, P. R., and J. R. Anderson (1992) Resources and Global Food Prospects: Supply and Demand for Cereals to 2030. Washington, D.C., World Bank. (World Bank Technical Paper No. 184.)

Crosson, P. R., and J. R. Anderson (1993) Concern for Sustainability: Integration of Natural Resource and Environmental Issues in the Research Agendas of NARS. Hague. (ISNAR Research Report No. 4.)

de Graaff, P. (1993) Soil Conservation and Sustainable Land Use: An Economic Approach. The Netherlands: Royal Tropical Institute.

Dregne, H. E. (1990) Erosion and Soil Productivity in Africa. Journal of Soil and Water Conservation 45:4 432-36.

Dregne, H. E. (1992) Erosion and Soil Productivity in Asia. Journal of Soil and Water Conservation 47:1 8-13. 
Dregne, Harold E., and Nan-Ting Chou (1992) Global Desertification: Dimensions and Costs. In H. E. Dregne (eds) Degradation and Restoration of Arid Lands. Texas: Texas Tech University, Lubbock. 249-82.

Duriappah, A. (1996) Poverty and Environmental Degradation: A Literature Review and Analysis. IIED, Amsterdam. (CREED Working Paper Series No. 8.)

Durning, A. B. (1989) Poverty and Environment: Reversing the Downward Spiral. November. World Watch, Washington, D.C. (World Watch Paper No. 92.)

FAO (1989) Soil Conservation for Small Farmers in the Humid Tropics. FAO Soil Bulletin 60. Rome.

Grepperud, S. (1997) Poverty, Land Degradation and Climatic Uncertainty. Oxford Economic Papers 49:4 586-608.

Grisley, W. (1980) Effects of Risk and Risk Aversion on Farm Decision-making: Farmers in Northern Thailand. PhD. dissertation, University of Illinois, Champagne-Urbana.

Hardin, G. J. (1968) The Tragedy of the Commons. Science 162: 1234-1248.

Harrison, P. (1984) Land, Food and People. Based on the FAO/UNFPA/IIASA Report, Potential Population-supporting Capacities of Lands in the Developing World. Food and Agriculture Organisation of the United Nations, Rome.

Hayami, Y., and V. W. Ruttan (1985) Agricultural Development: An International Perspective. Baltimore: Johns Hopkins University Press.

Hecht, S. (1985) Environment, Development and Politics: Capital Accumulation and the Livestock Sector in Eastern Amazonia. World Development 13:6 663-84.

Higgins, G. M., A. H. Kassam, L. Naiken, G. Fischer, and M. M. Shah (1983) Potential Population Supporting Capacities of Lands in the Developing World. Rome: International Institute for Applied Systems Analysis, Food and Agriculture Organisation of the United Nations, United Nations FPA.

IFAD (1992) The State of World Rural Poverty: An Inquiry into Its Causes and Consequences by I. Jazairy, M. Alamgir and T. Panuccio. New York: New York University Press.

Jodha, N. S. (1985) Population Growth and the Decline of Common Property Resources in India. Population and Development Review 2:2 247-64.

Jodha, N. S. (1986) Common Property Resources and Rural Poor in Dry Regions of India. Economic and Political Weekly 21: 1169-1181.

Jodha, N. S. (1991) Rural Common Property Resources: A Growing Crisis. International Institute for Environment and Development, London. (Gatekeeper Series No. S24.)

Joshi, P. K., and D. Jha (1991) Farm-level Effects of Soil Degradation in Sharda Sahayak Irrigation Project. Working Papers on Future Growth in Indian Agriculture, No. 1, Central Soil Salinity Research Institute, ICAR and International Food Policy Research Institute. September. 
Kilasara, M., I. K. Kullaya, F. B. S. Kaihura, J. B. Aune, B. R. Singh, and R. Lal (1995) Impact of Past Soil Erosion on Land Productivity in Selected Ecological Regions of Tanzania. Norwegian Journal Agricultural Sciences Supplement No. 21: 71-80.

Kumar, S., and D. Hotchkiss (1988) Consequences of Deforestation for Women's Time Allocation, Agricultural Production and Nutrition in Hill Areas of Nepal. October. (IFPRI Research Report No. 69.)

Lal, R. (1990) Soil Erosion and Land Degradation: The Global Risks. In Lal and Stewart (eds) Soil Degradation, Volume 11, Advances in Soil Science, New York. Springer-Verlag. 129-172.

Lal, R. (1995) Erosion-crop Productivity Relationships for Soil of Africa. Soil Science Society of America Journal 59:3 661-667.

Lal, R., G. F. Hall, and F. P. Miller (1989) Soil Degradation: Basic Processes. Land Degradation and Rehabilitation 1: 51-69.

Lindert, P. (1996) The Bad Earth? China's Agricultural Soils Since the 1930s. Agricultural History Centre, University of California, Davis, California. December. (Working Paper Series No. 83.)

Lipton, M. (1997) Accelerated Resource Degradation by Agriculture in Developing Countries? The Role of Population Change and Responses to it. In S. A. Vosti and T. Reardon (eds) Sustainability, Growth, and Poverty Alleviation. Baltimore: Johns Hopkins University Press.

Lipton, M. (1997a) Exogenous Interest Rates, Technology and Farm Prices versus Endogenous Conservation Incentives and Policies. In S. A. Vosti and T. Reardon (eds) Sustainability, Growth, and Poverty Alleviation. Baltimore: Johns Hopkins University Press.

Littleboy, M., A. L. Coggle, G. D. Smith, K. P. C. Rao, and D. F. Yule (1996) Soil Management and Production of Alfisols in the Semi-arid Tropics. Part IV. Simulating Decline in Productivity Caused by Soil Erosion. Australian Journal of Soil Research 34.

Lutz, E., S. Pagiola, and C. Reiche (eds) (1994) Economic and Institutional Analyses of Soil Conservation Projects in Central America and the Caribbean. A CATIEWorld Bank Project. The World Bank, Washington, D.C. (World Bank Environment Paper Number 8.)

Mabbutt, J. A. (1978) The Impact of Desertification as Revealed by Mapping. Environmental Conservation 5: 45-56.

Malik, S. J. (1999) Rural Poverty And Land Degradation: A Reality Check for the Consultative Group on International Agricultural Research. A Report prepared for the Technical Advisory Committee of the Consultative Group on International Agricultural Research, Rome. (Mimeographed.)

Malik, S. J. (1997) Background Report on the Poverty Study. OED, World Bank. 
(Mimeographed.)

McIntire, J. (1994) A Review of the Soil Conservation Sector in Mexico. In E. Lutz, S. Pagiola and C. Reiche (eds) Economic and Institutional Analysis of Soil Conservation Projects in Central America and the Caribbean. A CATIE-World Bank Project, Washington, D.C. 107-130. (World Bank Environment Paper No. 8.)

Migot-Adholla, S. et al. (1991) Indigenous Land Rights Systems in Sub-Saharan Africa: A Constraint on Productivity. World Bank Economic Review 5.

Mink, S. D. (1993) Poverty, Population and the Environment. Washington, D.C. (World Bank Discussion Paper No. 189.)

Mortimore, M. J. (1989) Adapting to Drought: Farmers, Famines, and Desertification in West Africa. Cambridge: Cambridge University Press.

Nelson, M. et al. (1997) Report of the Study on CGIAR Research Priorities for Marginal Lands. CGIAR, TAC Secretariat, FAO, TAC Working Document.

Oodit, D., and U. E. Simonis (1992) Poverty and Sustainable Development. In F. Ditelz, U. E. Simonis and J. Siraaten (eds) Sustainability and Environmental Policy. Berlin.

Oldeman, L. R., R. T. A. Hakkeling, and W. G. Sombroek (1991) World Map of the Status of Human-induced Soil Degradation: An Explanatory Note. Wageningen, International Soil Reference and Information Centre, Nairobi, United Nations Environment Programme. 27 pp + 3 maps. Revised edition. [quote 1992!!]

Pagiola, S. (1994) Economic Analysis of Environmental and Natural Resource Problems in Agriculture: Land Degradation in Developing Countries. Department of Economics and Food Research Institute, Stanford University. (Mimeographed.)

Pagiola, S. (1995) The Effects of Subsistence Requirements on Sustainable Land Use Practices. Presented at the Annual Meeting of the American Agricultural Economics Association. Indianapolis, August 6-9.

Pagiola, S. (1997) Environmental Problems in Moroccan Agriculture. In Morocco: Environmental Review and Action Strategy. Washington, D.C.: World Bank. Draft.

Pagiola, S., and J. Dixon (1997) Land Degradation Problems in El Salvador. Annex 7. World Bank, Washington, D.C. August. (El Salvador Rural Development Study Report \#16253-ES.)

Pender, J. L., and T. S. Walker (1990) Experimental Measurement of Time Preferences in Rural India. ICRISAT. (Economics Group Progress Report, Number 97.)

Pieri, C. et al. (1995) Land Quality Indicators. Washington, D.C. (World Bank Discussion Paper No. 315.)

Pimentel, D. et al. (1995) Environmental and Economic Costs of Soil Erosion and Conservation Benefits. Science 267: 1117-1123. 
Pimentel, D., J. Allen, and A. Beers (1993) Soil Erosion and Agricultural Productivity. In D. Pimentel (ed) World Soil Erosion and Conservation. Cambridge: Cambridge University Press. 277-92.

Pingali, P. L., Y. Bigot, and H. P. Binswanger (1987) Agricultural Mechanisation and the Evolution of Farming Systems in Sub-Saharan Africa. Baltimore: Johns Hopkins University Press.

Place, F., and P. B. R. Hazell (1993) Productivity Effects of Indigenous Land Tenure Systems in Sub-Saharan Africa. American Journal of Agricultural Economics 75: (February) 10-19.

Reardon, T., and S. Vosti (1997) Poverty-Environment Links in Rural Areas of Developing Countries. In S. Vosti and T. Reardon (eds) Sustainability, Growth, and Poverty Alleviation: A Policy and Agroecological Perspective. Baltimore: John Hopkins University Press.

Repetto, R. W. (1988) Economic Policy Reform for Resource Conservation. Washington, D.C.: World Bank. (Environment Department Working Paper No. 4.)

Repetto, R., W. Magrath, M. Welk, C. Beer, and F. Rossini (1989) Wasting Assets. Washington, D.C.: World Resources Institute.

Rozelle, S., J. Huang, and L. Zhang (1997) Poverty, Population and Environmental Degradation in China. Food Policy 22:3 229-251.

Rozelle, S., G. Veeck, and J. Huang (1997) The Impact of Environmental Degradation on Grain Production in China's Provinces. Forthcoming in Economic Geography.

Rutenberg, H. (1980) Farming Systems in the Tropics, 3rd Edition. Oxford: Clarendon House.

Scherr, S., L. A. Jackson, and S. Templeton (1995) Living on the Edge: Crafting Land Use Policies for the Tropical Hillsides in 2020. Paper presented at the workshop on Land Degradation in the Developing World: Implications for Food, Agriculture and the Environment to the Year 2020. International Food Policy Research Institute. Annapolis MD USA April 4-6.

Scherr, S. J. (1998) Is Soil Degradation a Threat to Developing Country Food Security? Food, Agriculture, and Environment Discussion Paper (Forthcoming) IFPRI, Washington, D.C.

Scherr, S. J., and S. Yadav (1995) Land Degradation in the Developing World: Implications for Food, Agriculture, and the Environment to 2020. IFPRI, Washington, D.C. (Food Agriculture and the Environment Discussion Paper 14.)

Seghal, J., and I. P. Abrol (1994) Soil Degradation in India: Status and Impact. New Delhi: Oxford and IBH.

Sillers, D. A. (1980) Measuring Risk Preferences of Rice Farmers in Nueva Ecija, Philippines: An Experimental Approach. Ph.D. Dissertation, Yale University, 
New Haven.

Smaling, E. M. A., J. J. Stoorvogel, P. N. Windmeijer (1993) Calculating Soil Nutrient Balances in Africa at Different Scales: District Scale. Fertiliser Research 35: 237-250.

Southgate, D. (1988) The Economics of Land Degradation in the Third World. Washington, D.C. (World Bank Environment Department Working Paper No. 2.)

Southgate, D. (1990) The Causes of Land Degradation along Spontaneously Expanding Agricultural Frontiers in the Third World. Land Economics 66:1.

Stark, O. (1991) The Migration of Labour. Oxford: Basil Blackwell.

Steiner, R. A., and R. W. Herdt (eds) (1993) A Global Directory of Long-Term Agronomic Experiments (Volume 1: Non-European Experiments). New York: The Rockefeller Foundation.

Stocking, M., and J. Benites (eds) (1996) Erosion-Induced Loss in Soil Productivity: Second Workshop: Preparatory Papers and Country Report Analyses. Rome: Food and Agriculture Organisation of the United Nations.

Stoorvogel, J. J., E. M. A. Smaling, and B. H. Janssen (1993) Calculating Soil Nutrient Balances in Africa at Different Scales: Supra-national Scale. Fertiliser Research 35: 227-335.

Tiffen, M., and M. Mortimore (1994) Malthus Converted: The Role of Capital and Technology in Growth and Environment Recovery in Kenya. World Development 22:7 997-1010.

UNCOD (1977) Round-up, Plan of Action and Resolutions. United Nations Conference on Desertification, Nairobi, Kenya. 43 pp.

UNEP (1980) Study on Financing the United Nations Plan of Action to Combat Desertification. Report to the Secretary-General. UNEP, A/35/396. Nairobi, Kenya. 5 p. and Annex 66 p. (Mimeographed).

Veloz. A., D. Southgate, F. Hitzhusen, and R. Macgregor (1985) The Economics of Erosion Control in a Subtropical Watershed: A Dominican Case. Land Economics 61:2 145-55. van Lynden and Oldeman. 1997. ASSOD.

Walker, T. S. (1981) Risk and Adoption of Hybrid Maize in El Salvador. Food Research Institute Studies 18.

Wasson, R. (1987) Detection and Measurement of Land Degradation Processes. In Chisholm and Dumsday (eds) Land Degradation: Problems and Policies. London: Cambridge University Press.

White, A., and J. Jickling (1994) An Economic and Institutional Analysis of Soil Conservation in Haiti. In Lutz et al. (eds) op cit. pp. 98-106.

World Bank (1990) World Development Report. New York: Oxford University Press.

World Bank (1991) World Development Report. New York: Oxford University Press. 
World Bank (1991a) Towards a Research Agenda for the World Bank on Land Degradation. Proceedings of an Informal Workshop on Land Degradation, Washington, D.C. January.

World Bank (1992) World Development Report. New York: Oxford University Press.

Young, A. (1993) Land Degradation in South Asia: Its Severity, Causes, and Effects Upon the People. Final Report Prepared for Submission to the Economic and Social Council of the United Nations (ECOSOC). FAO, UNDP and UNEP, Rome. 